\begin{tabular}{|l|l|l||}
\hline \multicolumn{2}{|c|}{ PublisherInfo } \\
\hline \hline PublisherName & $:$ & BioMed Central \\
\hline \hline PublisherLocation & $:$ & London \\
\hline \hline PublisherImprintName & $:$ & BioMed Central \\
\hline \hline
\end{tabular}

\title{
Breast Cancer On-line
}

\begin{tabular}{||l|l|l||}
\hline \multicolumn{2}{|c|}{ ArticleInfo } \\
\hline \hline ArticleID & $:$ & 3680 \\
\hline \hline ArticleDOI & $:$ & $10.1186 /$ bcr-2000-2-webreport0013 \\
\hline \hline ArticleCitationID & $:$ & 0013 \\
\hline \hline ArticleSequenceNumber & $:$ & 46 \\
\hline \hline ArticleCategory & $:$ & Web Report \\
\hline \hline ArticleFirstPage & $:$ & 1 \\
\hline \hline ArticleLastPage & $:$ & 3 \\
\hline \hline & $:$ & RegistrationDate : 2000-4-13 \\
ArticleHistory & $:$ & OnlineDate \\
\hline \hline ArticleCopyright & $:$ & Current Science Ltd2000-4-13 \\
\hline \hline ArticleGrants & $:$ & \\
\hline \hline ArticleContext & $:$ & 1305822 \\
\hline \hline
\end{tabular}




\section{Overview}

Sponsored by an educational grant from AstraZeneca Pharmaceuticals. Although this website is primarily clinically orientated, it also serves to integrate the latest scientific developments in breast cancer research. Within the site there are two literature review services: 'Journals Watch' which is updated twice monthly and provides a cumulative list of relevant articles with brief descriptions; and the clinical and basic sciences 'Journals Club' containing more lengthy reviews, but which are updated less frequently. The 'Focus On' section contains more in-depth reviews on specific topics and presently includes a review of current concepts in breast reconstruction. Full colour images of breast cancer pathology can be found within the 'Visual Library' section. The 'Information/Support' section includes reports from the major clinical breast cancer meetings, and provides useful links to other medical websites and databases. 'Interactive Modules' provides access to discussion forums and allows readers to submit case studies for expert opinions. One particularly interesting feature offered is the interactive 'Self-Assessment Module' which provides an opportunity to test one's knowledge and receive instant feedback.

\section{Content}

A fairly well organised and simple to navigate site for the intermediate user. All pages have a 'back to' link and externally linked sites appear within the Breast Cancer On-Line frame facilitating navigation. In addition, the site is fully searchable.

\section{Timeliness}

This site seems to be updated fairly frequently although the homepage does not give any indication.

\section{Evaluation}

Registration is required for this site, but is easily completed and a helpful section is also provided to assist with 'logging on' and printing. This site provides a wide range of information which is well presented and deserves a visit. 


\section{References}

1. Breast Cancer Online. [http://www.bco.org/]

This PDF file was created after publication. 